
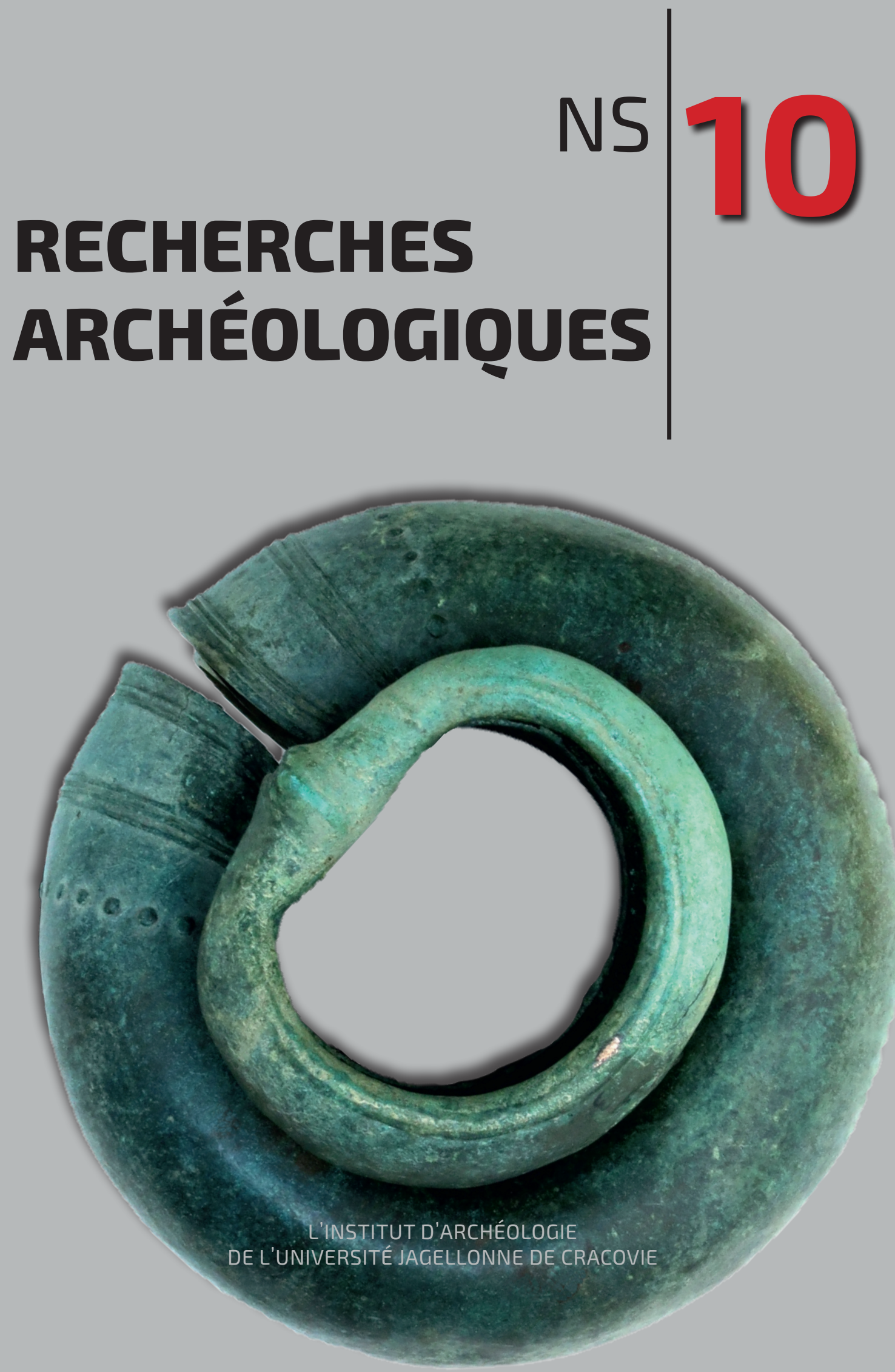
RECHERCHES ARCHÉOLOGIQUES NOUVELLE SERIE 

L'INSTITUT D'ARCHÉOLOGIE

DE L'UNIVERSITÉ JAGELLONNE DE CRACOVIE

RECHERCHES ARCHÉOLOGIQUES

NOUVELLE SERIE 10

(2018)

KRAKÓW 2019 
(C) Copyright by Institute of Archaeology of the Jagiellonian University, Kraków 2019

\author{
RÉDACTEUR EN CHEF \\ Przemysław Nocuń \\ SÉCRETAIRE DE LA RÉDACTION \\ Michał Kasiński \\ COMITÉ DE RÉDACTION
}

Jan Chochorowski, Krzysztof Ciałowicz, Ulla Lund Hansen, Renata Madyda-Legutko, Vjacheslav I. Molodin, Ewdoksia Papuci-Władyka, Jacek Poleski, Pál Raczky, Paweł Valde-Nowak

RÉDACTEURS DU SUJET

Wojciech Blajer, Janusz Ostrowski, Krzysztof Sobczyk, Joachim Śliwa

COMITÉ DE LECTURE

Dagmara Adamska, Justyna Baron, Małgorzata Chorowska, Adam Cieśliński, Katarzyna Czarnecka, Przemysław Dulęba, Jan Jílek, Maciej Kaczmarek, Andrzej Maciałowicz, Marcin Maciejewski, Kyrilo Myzgin, Marcin S. Przybyła, Marzena Przybyła, Tomasz Ratajczak, Judyta Rodzińska-Nowak, Sławomir Sprawski, Michał Wojenka

ÉDITEURS DE LANGUE

Piotr Godlewski, Keith Horechka

MAQUETTE DE COUVERTURE, MISE EN PAGES

Wydawnictwo i Pracownia Archeologiczna PROFIL-ARCHEO Magdalena Dzięgielewska

ADRESSE DE LA RÉDACTION

Instytut Archeologii Uniwersytetu Jagiellońskiego, ul. Gołębia 11, PL 31-007 Kraków

www.farkha.nazwa.pl/RechACrac/

www.archeo.uj.edu.pl/RechACrac/

La version originale des Recherches Archéologique Nouvelle Serie est la version papier

"Recherches Archéologiques Nouvelle Serie" est régulièrement sur la liste dans The Central European Journal of Social Sciences and Humanities

Podniesienie poziomu umiędzynarodowienia tomów nr 9 i 10 czasopisma "Recherches Archéologiques, Nouvelle Serie" - zadanie finansowane w ramach umowy nr 606/P-DUN/2018 ze środków Ministerstwa Nauki i Szkol-

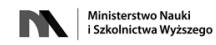
nictwa Wyższego przeznaczonych na działalność upowszechniającą naukę

ISSN 0137-3285

Publikacja finansowana przez Uniwersytet Jagielloński

Cette publication est financée par l'Université Jagellonne 


\section{CONTENU}

\section{ÉTUDES}

Wojciech Blajer: Some remarks on socketed axes of the Passau type

Karol Dzięgielewski, Anna Longa, Jerzy Langer, Magdalena Moskal-del Hoyo: Contextualisation of the Early Iron Age hoard of bronze objects discovered in Gdynia-Karwiny, site 1

Przemysław Dulęba: New data for studies on settlement and economy of the La Tène culture in Lower Silesia

Przemysław Dulęba: La Tène culture in Silesia. Remarks on the state of research and new cognitive perspectives

Krzysztof Michalczewski, Jan Bulas: Flat scrapers made of bone from Pre-Roman and Roman Period on the Polish Lands

Dariusz Niemiec: $13^{\text {th }}$-century fortifications of Kraków

Jarosław Bodzek, Kamil Kopij, Szymon Jellonek, Barbara Zając: Studies on Roman coin finds from the Central European Barbaricum in the Institute of Archaeology of the Jagiellonian University - an overview

\section{RAPPORTS}

Michał Kasiński, Jan Bulas, Magdalena Okońska: A newly discovered Przeworsk culture settlement and burial ground from the Late Pre-Roman and Roman period at Bejsce, Dist. Kazimierza Wielka - preliminary results of field-walking survey and rescue excavations

Joanna Zagórska-Telega, Jacel Pikulski, Anita Szczepanek: Archaeological excavations of multicultural site 1 at Michałowice, Commune Czarnocin, in seasons 2013-2014

Paulina Kowalczyk-Matys: Figural tile from the first half of the $16^{\text {th }}$ century with a young man from Jagiellońska Street in Kraków 


\title{
Pre-Roman and Roman Period flat scrapers made of bone in the territory of Poland
}

\begin{abstract}
Bone tools are among the least studied artefacts, not only in the Przeworsk culture but in other regions of European Barbaricum as well. In the article, the focus is on one type of bone tool, flat scrapers, which have not as yet been sufficiently analysed. The first conclusion is that this category of finds is more widespread than previously assumed and has often been misinterpreted. One of the most interesting findings presented in the text concerns the function of those tools. Their function is reconstructed here based on the analysis of unpublished specimens recently discovered in Przeworsk culture settlements in the basins of the Nida and Nidzica Rivers, and on analysis of the published materials. Microscopic analysis of micro-traces was conducted in order to examine the proposed hypotheses. As a result, an interpretation of the spread, function, and chronology of scrapers made of bone is proposed.
\end{abstract}

Keywords: bone tools, scraper, hide-working, Przeworsk culture

Bone tools are rarely the subject of separate publications related to the Late Pre-Roman and Roman Periods in Poland. It seems that this situation is a result of marginalization of items of this type, caused by lack of knowledge among many archaeologists about worked bones and little interest in items which are often claimed to be less "prestigious". At this point it should be admitted that a wide range of artefacts discovered at the sites related to the discussed period indeed absorb a considerable amount of research effort, often leaving bone tools at the end of the list of "interesting" finds. Undoubtedly, the small number of papers concerning worked bones from this period also stems from the fact that not in every region do the soil conditions allow for discovering bones, which makes them a category of finds not so commonly registered. Another factor impacting this state of affairs is the lack of overview of the material discovered at the site, which often leaves fragmentarily preserved finds unrecognized. Undeniably, bone tools are artefacts that require more attention of the archaeological community, and the increased

1 Institute of Archaeology, Jagiellonian University; 11 Gołębia St., 31-007 Kraków, Poland; krzysztofmichalczewski@gmail.com

2 Institute of Archaeology, Jagiellonian University; 11 Gołębia St., 31-007 Kraków, Poland; bulas.jan@gmail.com 
publication of bone tools will slowly expand the knowledge about the patterns of Iron Age economy and about the relationship between humans and the natural environment as well.

The aim of this paper is to make an attempt to define the function of the bone plaques with two perforations based on the finds discovered in recent years at the sites of Przeworsk culture in the interfluve of the Nida and Nidzica Rivers. Moreover, these new finds will be analysed in the context of the already published examples discovered throughout the area occupied by the Przeworsk culture (Fig. 1) Archaeological excavations and surveys conducted in 2012-2018 at La Tène and Roman Period settlements located in Kazimierza Wielka District, Świętokrzyskie Voivodeship, yielded eight items of this type (five in Michałowice, ${ }^{3}$ two in Rzemienowice, ${ }^{4}$ and one in Zagórzyce, ${ }^{5}$ all Kazimierza Wielka District). Analogous tools were also recorded on other sites, ${ }^{6}$ but their function has not been clearly determined. The majority of them have been defined as weaving tools (Cofta-Broniewska 1979, 110; Andrzejowski 1998, 21; Kokowski 1999, 92-93; Stasiak-Cyran 2016, 31, 79) or hide-working tools (Malinowski 1961, 65; Skowron 2006, 80-81; Diakowski 2014, 135). On the basis of the use-wear analysis of the working surface, comparison to other tools of similar shape but having known function, and on the basis of ethnographic studies, we claim that these tools were used for hide-working. This publication is also an attempt to clarify the chronology of the described artefacts.

\section{Description of the tools}

All the described tools are made of flat, thin bone plaques, up to $7 \mathrm{~mm}$ thick. They do not have a standardized shape. They take numerous forms - semicircular, trapezoidal, and rectangular (Fig. 2). Their shape is determined by the natural structure of the bone chosen as raw material for the tool. The most characteristic feature distinctive for these tools is the presence of two small round perforations (4 to $6 \mathrm{~mm}$ in diameter) on the longer edge, opposite to the working edge (which is sharpened and polished).

Among the artefacts for which it was possible to determine the anatomical provenance of the bone, the majority were made of the mandible of large mammals, most probably cattle, which was confirmed on the basis of the analysis of the numerous waste fragments found at archaeological sites. One tool only was made of the scapula of a small ruminant.

The described bone tools were discovered at three different settlements located in the same region. At the site in Michałowice (site 20) examined in 2012-2014, two phases of occupation were identified. The first one was related to the La Tène culture and the second with the Przeworsk culture, which occupied the site in the Late pre-Roman and Early Roman Periods. One

\footnotetext{
${ }^{3}$ The research at Michałowice site 20 in 2012-2014 was conducted by Michał Kasiński, PhD and Jan Bulas, MA from the Institute of Archaeology of the Jagiellonian University.

${ }^{4}$ The archaeological research in Rzemienowice has been conducted since 2016 by a team of archaeologists associated with the Jagiellonian University (M. Kasiński, PhD; J. Bulas, MA; M. Okońska, MA). In the initial years the research was conducted in cooperation with P. Wroniecki, MA, who performed noninvasive research financed by the NCN Preludium program (2014/15/N/HS3/01719).

${ }^{5}$ The excavations of the complex of Roman Period sites in Zagórzyce took place in 2002-2008 (Grygiel, Pikulski 2006; Grygiel et al. 2009; Bodzek et al. 2016). However, the artefact described in this paper was discovered during a survey organized within the framework of classes for Jagiellonian University archaeology students in 2016.

${ }^{6}$ We would like to thank above all Professor Renata Madyda-Legutko and Professor Judyta RodzińskaNowak for their help in obtaining information about unpublished specimens.
} 


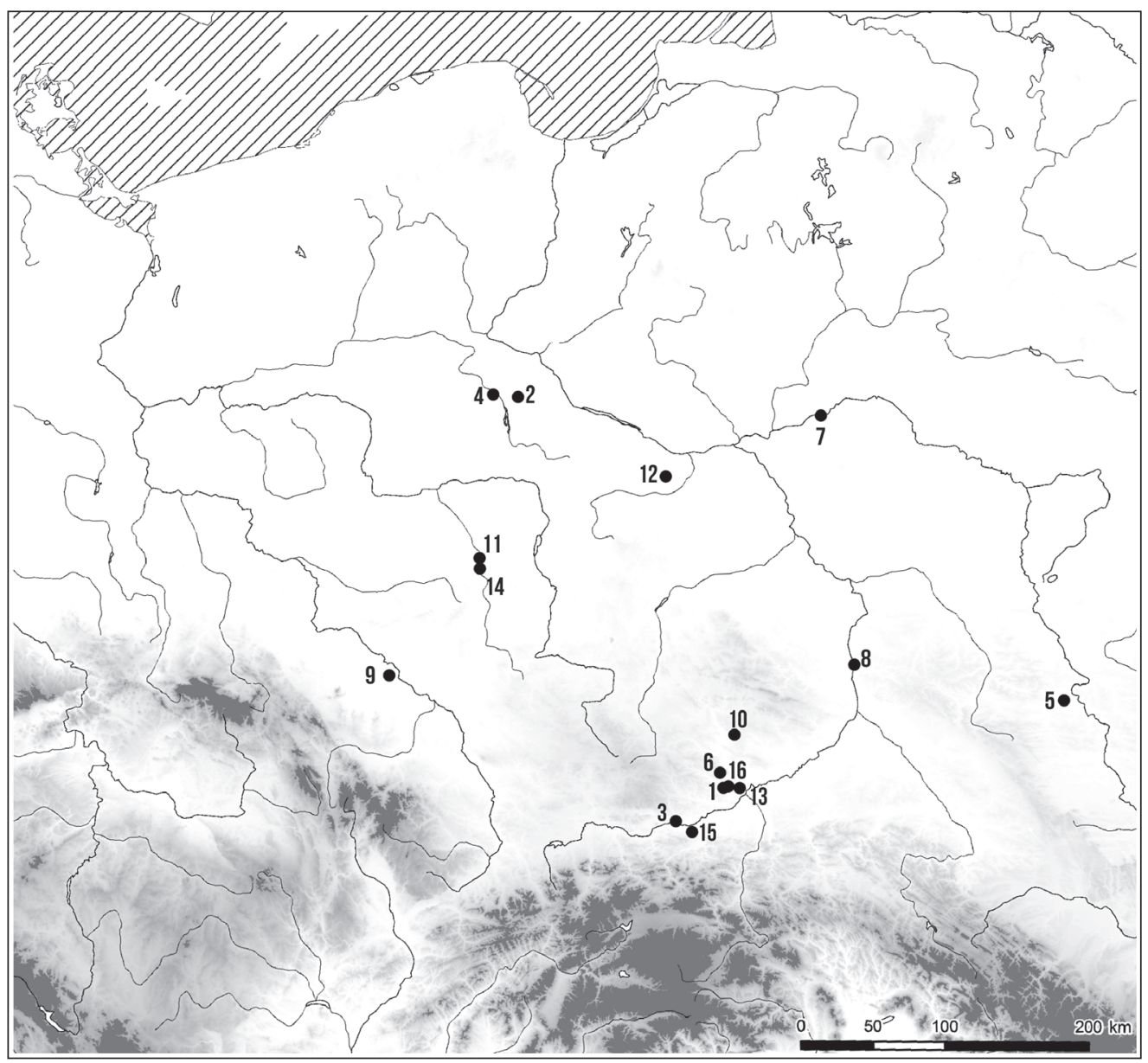

Fig. 1. Distribution of bone scrapers in the territory of Poland: 1. Jakuszowice, 2. Konary, 3. KrakówNowa Huta, 4. Krusza Zamkowa, 5. Masłomęcz, 6. Michałowice, 7. Nadkole, 8. Nieszawa-Kolonia, 9. Lizawice, 10. Oględówek, 11. Piwonice, 12. Różyce-Stara Wieś, 13. Rzemienowice, 14. Zadowice, 15. Zagórze, 16. Zagórzyce

should note that on the basis of the obtained material it is most probable that the settlement was not used in the Younger Roman Period. In Michałowice, four well-preserved bone scrapers (Fig. 2: 3-6) and one fragment (Fig. 2: 1) with the preserved part with two round perforations were discovered. It was possible to determine that two of them were made from a mandible and one from a scapula. Two other artefacts did not have features allowing to distinguish which flat bone was used to manufacture them. These bone tools were discovered during two excavation seasons (2012 and 2014). Interestingly, three bone scrapers found in 2012 were lying close to each other in the accumulation layer ${ }^{7}$ which was covering the ceilings of archaeological features. Near the place where the bone scrapers were found, a lime kiln and a hearth were discovered. It is difficult

${ }^{7}$ By this we mean a layer created as an effect of accumulation of debris created by the inhabitants of the settlement and by post-depositional processes, sometimes referred to as a cultural layer. 

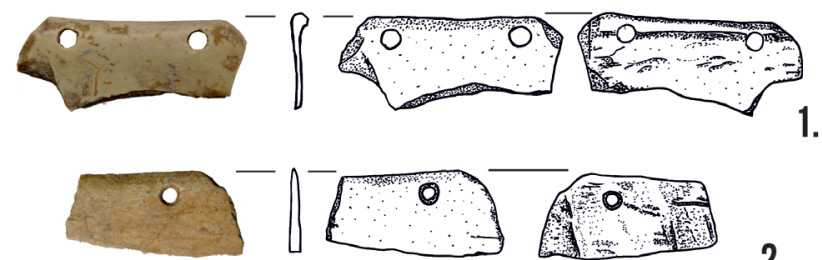

2.

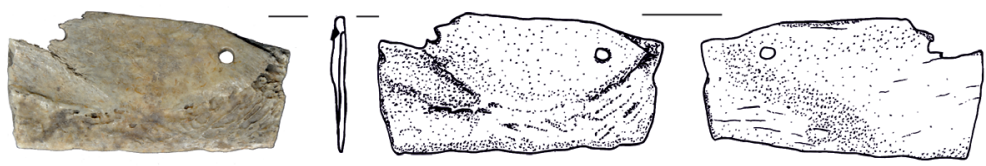

3.
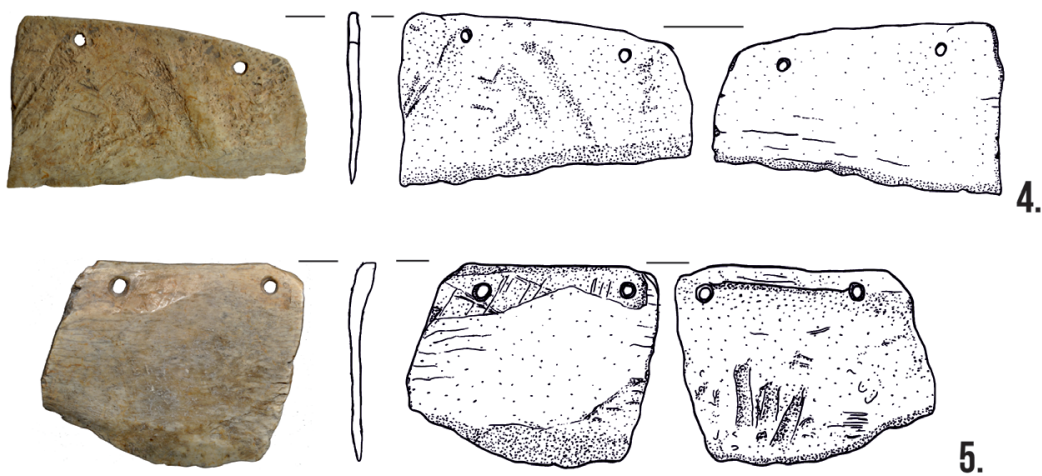

5.
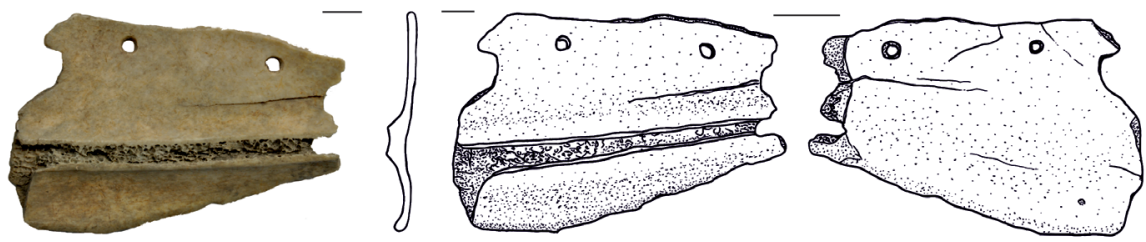

6.
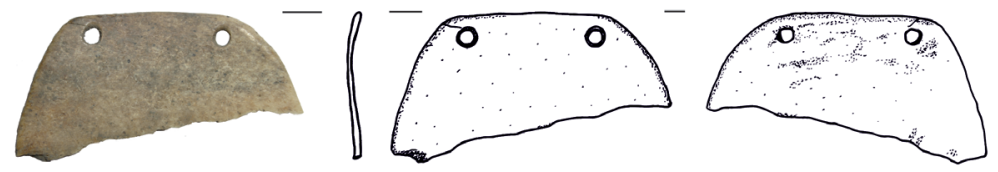

7.

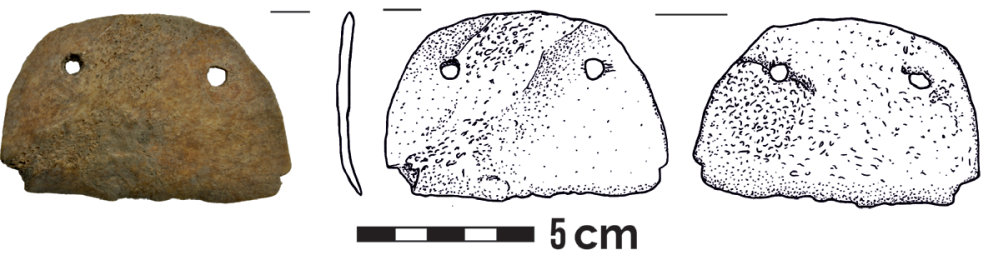

8.

Fig. 2. Scrapers made of bone: Michałowice: 1, 3-6; Rzemienowice: 2, 8; Zagórzyce: 7 
to define a direct relation between these features and the bone scrapers, but certainly a connection between them cannot be excluded. It is a known fact that in medieval Poland lime was used in the process of preparation of hide for further processing (Turnau 1983). Other bone scrapers were found outside the archaeological features as well, in the accumulation layer. It is worth mentioning that they were also discovered at a short distance from features of manufacturing character, which are however more difficult to interpret. Also of importance, at the settlement in Michałowice many traces of bone processing were observed (Bulas et al. 2019) including the wide range of semi products, waste, and bone artefacts of different types. The presence of bone scrapers and manufacturing waste and the proximity of the lime kiln suggest that in this part of the site activities connected with hide-working took place.

The settlement in Rzemienowice is a multiphase site, like Michałowice related mainly to the La Tène and Przeworsk cultures ${ }^{8}$. However, in contrast to the latter site, the settlement in Rzemienowice is dated to the Younger and Late Roman Periods and the Early Migration Period as well. Two hide-working tools of the discussed type have been discovered in Rzemienowice so far (Fig. 2: 2, 8). One of them, made from a mandible (cattle?) was preserved very well, while in the second tool the working edge is missing, but the remains of the roots of the teeth allows for concluding that it was made from a mandible bone as well. Unlike the artefacts found in Michałowice, these were discovered inside archaeological features. Both were found in pit-houses. The first tool comes from a feature dated to the Early Roman Period, probably to phase B2. The second was found in a younger feature, dated to phase $\mathrm{C}$ of the Roman Period ${ }^{9}$. Furthermore, it is worth mentioning that at Rzemienowice no materials which could allow connecting the excavated area with manufacturing activities (like in Michałowice) have as yet been discovered. However, this state may result from the fact that only a small part of the site has been excavated so far.

At site 1 in Zagórzyce, where the last of the described hide scrapers (Fig 2: 7) was found, several settlement phases were recorded, spanning from the Neolithic to the Middle Ages. However, the majority of the discovered remains are connected with the Przeworsk culture occupation from the Late Pre-Roman and Early Roman Periods (Grygiel, Pikulski 2006; Grygiel et al. 2009). It should be pointed out that, as in the case of Michalowice, materials dated to the Younger Roman Period were not recorded at the site. Acknowledging the presence of the older and younger materials at the site, we connect this tool (found during a field-walking survey) with the Przeworsk culture based on analogical finds listed in this article. Nevertheless, theoretically, it cannot be excluded that it is connected with a different chronological phase, represented at this site.

\section{Analogies}

Scrapers made from bone which can be described as direct analogies to the finds discussed here are known from Roman Period sites in Poland. They are known from both contexts: cemeteries and settlements.

\footnotetext{
${ }^{8}$ In both cases a few finds connected with earlier chronological phases were recorded. They were discovered in the soil run-off layers and in Przeworsk culture features in secondary context. However, features which could be connected to the Neolithic or the Bronze Age have not been recorded so far. It is worth adding that even though La Tène culture material constitutes a considerable part of all finds, features and finds attributable to the Przeworsk culture prevail on both sites.

${ }^{9}$ In feature 1 there were no finds which would help to narrow down its chronology. Wheel-made pottery fragments found in feature 1 allowed the chronology to be widely determined as the Roman Period. In feature 1 other materials in the secondary context were also found e.g. a fragment of an Early Bronze Age stone axe.
} 
Several tools of this type were discovered at the settlement in Jakuszowice (Kazimierza Wielka District) (Fig. 3: 14-17), a short distance from the settlements discussed in this article (Michałowice, Zagórzyce and Rzemienowice). Two of these tools are in good state of preservation (Zielińska 2004, pl. XIIIa: 1, 2) and two are preserved only in fragmented pieces (Zielińska 2004, pl. XIIIc: 7, 8). On one bone tool, the teeth roots are clearly visible, which allows concluding that it was made from a mandibular bone. Their function had not been clearly described before. In a master's thesis devoted to bone items from Jakuszowice ${ }^{10}$ they were included in the section of "hafts". The two well-preserved scrapers found in layer 1 dated back to the Roman Period.

Three other analogies are known from places located relatively close to the archaeological sites mentioned above, from Świętokrzyskie and Małopolskie Voivodeships. An analogous tool was discovered at the Przeworsk culture settlement (feature 1) in Oględówek (Fig. 3: 5) (Pinczów District, Świętokrzyskie Voivodeship) (Niemiec 1999, 48, pl. XXVIII: 4). It was described as a semi-product for a comb.

Another analogical bone tool, identified initially as Eneolitihic, was discovered at site 1 in Kraków-Nowa Huta (Mogiła) (Fig. 3: 19) (Hachulska-Ledwos 1996, 39, 85, pl. XV: 21). In the central part of the working edge of this tool, notches cut intentionally into the edge are highly visible.

One more scraper was found in Zagórze (Niepołomice District) (Fig. 3: 1), although this find has not yet been published. Information about this find is provided in the report from research preceding motorway construction at site no. 2 in Zagórze ${ }^{11}$, which yielded materials of both the La Tène culture and the Tyniec group from the Pre-Roman Period and Early Roman Period. The bone scraper was found in a feature linked with the Tyniec group, dated back to the end of phase A3 of the Pre-Roman Period and beginning of phase B1.

Another analogical bone tool made from a mandible was discovered at the Przeworsk culture settlement in Lizawice, site 1, Oława District (Fig. 3: 3) (Diakowski 2014, 130). Based on traseological examination it was identified as a hide-working tool (Diakowski 2014, 135).

Three artefacts (one preserved only in a small fragment) which should be also included among analogies were found at settlement in Piwonice (near Kalisz) (Fig. 3: 10-12). In the publication, they were determined as "bone hafts with two perforations". One was discovered in house 54 , whose chronology was estimated to the $3^{\text {rd }} / 4^{\text {th }}$ century CE (Dąbrowski, Dąbrowska 1968, 464, 467; pl. XVII: 10). However, according to the current state of knowledge, this assemblage should be dated to the Early Roman Period. The second tool was found in feature 66 (Dąbrowski, Dąbrowska 1968, 473; pl. XX: 7) and it was also dated initially to the $3^{\text {rd }}$ century CE. In this case, the dating should be moved to the Early Roman Period as well. The scraper from feature 54 has a notched working edge (two teeth are clearly visible), as does the tool from Kraków-Nowa Huta (Mogiła). In the case of other scrapers, use-wear of the tool made the teeth of the notched edge barely visible. In the context of the same feature were found, among others, a considerable number of pottery pieces, a spindle whorl fragment, whetstones, and bronze needles (Dąbrowski, Dąbrowska 1968, 464).

\footnotetext{
${ }^{10}$ The material was studied in the master thesis by Magdalena Zielińska "Bursztyniarstwo, obróbka kości i poroża oraz tkactwo w młodszym okresie przedrzymskim i okresie wpływów rzymskich na stan. 2 w Jakuszowicach, gm. Kazimierza Wielka, woj. świętokrzyskie" written under the supervision of Professor P. Kaczanowski at Jagiellonian University.

${ }^{11}$ We would like to thank P. Dulęba PhD and R. Naglik M.A. for sharing the information about this artefact, whose description and photograph is included in the excavation report from site 2 in Zagórz, in the section concerning the settlement from the La Tène and Roman Periods.
} 



15.
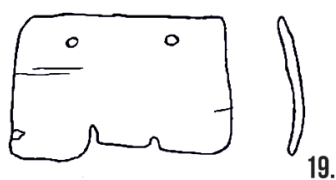

\section{$10 \mathrm{~cm}$}

18.

19.

Fig. 3. Analogies: 1. Zagórze, 2. Nadkole, 3. Lizawice, 4. Nieszawa-Kolonia, 5. Oględówek, 6. RóżyceStara Wieś, 7. Konary, 8-9. Krusza Zamkowa, 10-12. Piwonice, 13. Zadowice, 14-17. Jakuszowice, 18. Smuszewo, 19. Kraków-Nowa Huta (Mogiła)

The next analogy was recorded in the neighbourhood of Kalisz in Zadowice, Kalisz District (Fig. 3: 13). It was discovered in a feature dated back to the B1c and B2a phases. It was published as a hide-working tool (Siciński 2011, 59, 221, fig. 95).

Another one (Stasiak-Cyran 2016, 182, pl. LXXXIV, feature 72:5) was found at a settlement dated to the Roman Period in Nieszawa Kolonia (site 5), Opole Lubelskie District (Fig. $3: 4$ ). The tool was found in a storage pit (feature $72 \mathrm{~A}$ ) of $0.6-0.8 \mathrm{~m}$ in diameter, dated back to the Roman Period. The same feature contained fragments of pottery, charcoal, and daub. This scraper has a well-visible notch on the working edge. It was described as a weaving tool made from antler (Stasiak-Cyran 2016, 31, 79). 
A bone scraper of this type was also found at the settlement in Różyce Stara Wieś, Łowicz District (Fig. 3: 6) (Skowron 2006, 80, 232, pl. LXIII), in a feature dated back to the Late PreRoman Period. This artefact was interpreted and published as a tool connected with tanning.

Further analogies are known from sites located in Kuyavia (Cofta-Broniewska 1979). Two were recorded at site 3 in Krusza Zamkowa (Fig. 3: 8, 9) and one at site 28 in Konary (Fig. 3: 7) (Cofta-Broniewska 1979, 109, fig. 5). They were described as weaving tools (weaving swords) (Cofta-Broniewska 1979, 110). Moreover, one half-product (without drilled holes), which is possibly connected with manufacturing of these bone scrapers, was found at the site of Jacewo (Inowrocław District) (Cofta-Broniewska 1979, 111, fig. 6: 7). The sharpened edge of this half-product may confirm the hypothesis that it was prepared for a bone scraper, not for a comb (which also has a similar shape).

One bone scraper was found at the Lusatian culture settlement in Smuszewo, Wagrowiec District (Fig. 3: 18) (Malinowski 1961). The shape of the tool and the position of the two drilled holes are the same as in the case of the scrapers described above. Given that this find is unique for the Lusatian culture, we cannot exclude that it should be actually dated to the Roman Period. This tool was interpreted as a hide-working tool (Malinowski 1961, 65).

Several bone scrapers were found in female graves of the Przeworsk culture. One of them was recorded in female grave 21 at Nadkole 2 cemetery (Węgrów District) (Fig. 3: 2). The raw material was determined as a sheep/goat scapula. It was described as a weaving tool (Andrzejowski 1998, 21, 166, pl. XV: 20). Burial is dated back to the Early Roman Period.

The next one was found in grave 13 at the burial ground in Masłomęcz (Hrubieszów District) (Kokowski 1999, 92, figs 114a, 114b), dated back to the beginning of phase C1 of the Roman Period. A bone plaque with holes and a sharpened edge was found together with a tool with a polished edge made from a cattle rib. Both artefacts were described by A. Kokowski as weaving tools (Kokowski 1999, 93). However, both the tool made from a rib and the bone plaque with two holes could be used for tanning. Tools made from cattle ribs and having rounded edges are often described as hide scrapers (Rajewski 1950, 173; Drzewicz 2004, 21), but they can be used for pottery manufacturing as well (Łukasiewicz, Rajewski 1938, 48; Mărgărit 2015).

Analogical bone scrapers were found also at Roman Period settlements in the Czech Republic (two from Tuklaty, okr. Kolín, one from Starý Vestec, okr. Nymburk and one from Polepy, okr. Litoměřce) (Zeman 2001, 137, fig. 12: 21-24).

Although the listed analogies appear in the literature under different names and their functions are differently determined, ${ }^{12}$ they should all be described as representing one category of tools. Determining the function of the presented tools requires comprehensive analyses of the artefacts themselves and of the whole bone material found at the site, including possible halfproducts and waste connected with manufacturing of the described tools.

\section{Manufacturing waste}

Analyses of bone pieces from Rzemienowice and Michałowice allowed for identification of waste possibly connected with manufacturing of bone scrapers made from mandibles. The concentration of mandibular rami chopped off together with processus coronoideus and processus

\footnotetext{
12 The interpretation of the function of the abovementioned tools was based mostly on the researchers intuition. The only research which included traceological method is the one conducted by M. Diakowski (Diakowski 2014).
} 
condylaris, found in the context of bone scrapers, might be a result of such production. Moreover, in the same context, much waste in the form of split mandible corpus parts with visible tooth root remains was recorded. The most interesting waste is the mandible from Michałowice with the ramus and angle chopped off, and with the bottom part of the corpus removed (Fig. 4). Undoubtedly the waste of this shape, found in the same context as bone scraper made from the mandible, is connected with the manufacturing of these tools. Analysis of waste and half products and the dimensions of finished tools show that mandibles of cattle were the most common raw material for the manufacturing of these tools. However, the use of mandibles of other species cannot be excluded (Fig. 2: 2, 4, 5; 3: 1, 3, 5, 16). ${ }^{13}$

The waste pieces we examined might be also at the same time a result of dismembering mandibles and skulls (Binford 1981, 109). Fragmentation of mandibular bones is interpreted in some cases as the result of marrow extraction. However, extracting the marrow from a mandible can be done by just one strike which breaks substantia compacta (Outram 2002, 33). Some waste from sites discussed here is worked in a more complicated way. It is highly possible that first flesh was removed from the bone in a way that allowed using it as a future half-product for a scraper. Even though identification of waste related to the production of bone scrapers is a problematic task, the following conclusion can be made based on the planigraphy of the discovered materials. In both Michałowice and Rzemienowice sites, waste in the form of chopped-off rami was found close to the bone scrapers themselves. This is especially visible in feature 1 in Rzemienowice, where together with the bone scraper, six waste pieces of this type were recorded. In the case of the Michałowice settlement, this waste was concentrated in quarter D, where two tools of this type were found together with one particular waste fragment described above (Fig. 4).

When it comes to the scrapers made from scapula bone, no particular waste fragments which might be connected with their production were distinguished.

\section{Manufacturing traces}

On the waste probably connected with bone scrapers, production traces of chopping and cutting with metal tools are evident. Two holes were drilled with the use of a knife (Fig. 5: 1). Moreover, traces of sharpening the tool with a stone were also observed, particularly visible on the working edge (Fig. 5: 3). In the case of some scrapers, traces of handle attachment are clearly visible (Fig. 5: 2). At the place where a handle was present, the bone is not polished.

At the site in Michałowice, along with numerous bone finds iron and stone tools were also discovered, whose function probably should be associated with the processing of bone and antler. These included "miniature" knives, hooked wires, and stone tools that possibly were used for smoothing antlers.

\section{Round holes}

The presence of only one hole in a bone scraper is explained by some researchers working on similar bone tools from different periods and cultures as reflecting the custom of tying the tool to the wrist or belt (Lehmann 1931, 42; Griaznov 1956, 76; Northe 2001, 181; Zhilin 2014, 64).

\footnotetext{
${ }^{13}$ In most cases (Fig. 3: 2, 4, 6-13, 15, 17-19) identification of the raw material used cannot be done with certainty due to the quality of the drawing.
} 


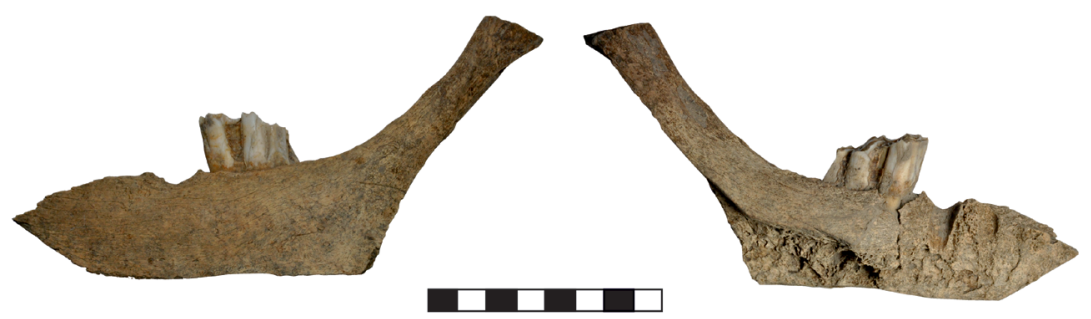

Fig. 4. A mandible with a chopped off ramus from Michałowice site 20

Some types of hide scrapers were provided with a strap which was tied at the wrist to help the user hold the tool stable and to protect it from slipping (Wiederhold 2004; Rašková Zelinková 2010, 192). Another hypothesis posits the use of a single hole to bind the tool with a wooden handle. It is believed that the presence of more than one hole is related to the repairing of a broken tool (Northe 2001, 181; Luik, Lang 2010, 167; Zhilin 2014, 22). In the case of the described objects, however, this view is not confirmed. All the objects with two symmetrically arranged holes are characterized by good condition and symmetrical form. It can therefore be assumed that in these cases the presence of two holes is not the result of the tool being repaired. Moreover, these tools are not worn out in the part where the holes are, where it is presumed handles could have been attached. M. Diakowski put forward a hypothesis based on micro-traces from the artefact from Lizawice that there was a handle attached to the scraper and the sliding movements performed during the use of the tool caused the formation of small scratches on the edge of the hole, opposite to the edge of the working tool (Diakowski 2014, 130). This is also visible on the specimens analysed here. The hole is blurred on one side, which suggests that it was caused by sliding movements typical of hide-working (Fig. 5: 1). It can therefore be stated with certainty that in the case of the discussed scrapers, one can talk about binding the object to an organic hilt, which has not been preserved.

\section{Use-wear traces}

All of the tools are characterized by smooth edges and polish, with the working edge (i.e. the side opposite to the edge with the holes) being the smoothest and most polished part. The working edge in the majority of scrapers is slightly wavy in the middle part, and in at least five examples (Piwonice, Zagórze, Kraków-Nowa Huta (Mogiła), Krusza Zamkowa - Fig. 3: $1,8-10,19)$ traces of cutting the notches are evident. The edge with the holes does not reveal strong wear. This probably results (as also noted by M. Diakowski in the case of the object from Lizawice) from an organic handle attached to this part of the tool.

The bone scrapers from Michałowice and Rzemienowice were subjected to traseological analysis. In addition to the strong polish and smoothening of the working part of the object, numerous scratches and micro-grooves have been observed. On some of the specimens, traces of sharpening of the working edge on the stone are clearly visible (Fig. 5: 3). Such traces were also observed on the photographs made using Scanning Electron Microscopy (Fig. 6). ${ }^{14}$ Most

\footnotetext{
${ }^{14}$ The photos taken with the use of SEM revealed interesting micro-traces, although more precise analysis of the observed scratches requires conducting microphotographs of more numerous objects and comparison of the results.
} 


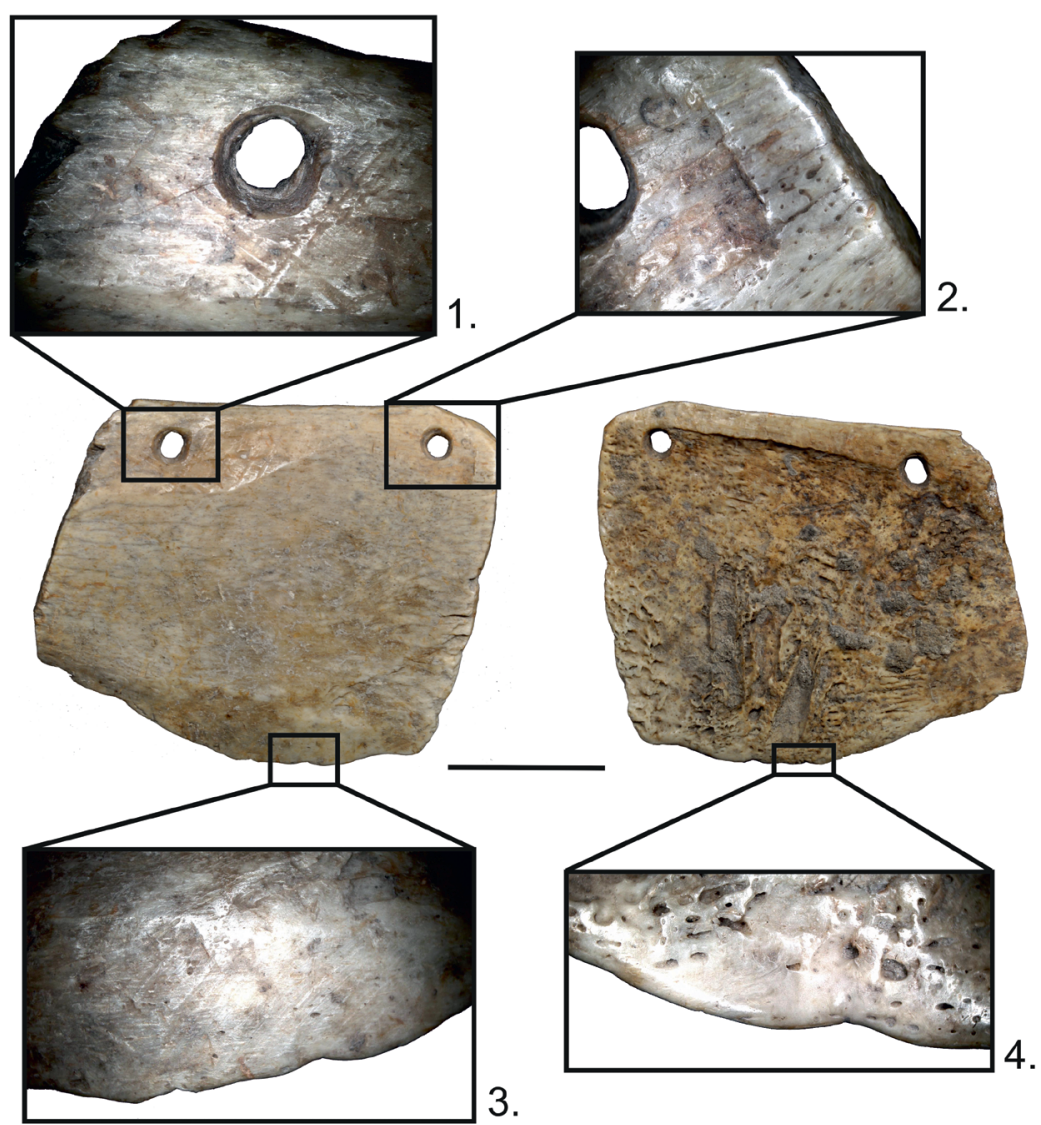

Fig. 5. Manufacturing traces and traces of wear on a scraper from Michałowice. 1) Holes drilled with a knife, 2) traces of hafting, 3) traces of sharpening the tool on a stone, 4) polished working edge (use-wear)

of the scratches on the very edge of the scraper are located perpendicular to the longer axis of the object. In its further part, the visible traces intersect at different angles (mainly at an angle of about 45 degrees). The nature of the polish resembles so-called "skin polish" (Grushin, Valkov 2014, 70), while the chaotically arranged scratches stem from the presence of dust or dirt during the use of the tool (Zhilin 2014, 64). The traces we have observed are analogous to the traces observed on the tool from Lizawice (Diakowski 2014, 129, fig.7: e). M. Diakowski describes them as traces of defleshing (Diakowski 2014, 129). Similar traces are visible on scrapers from the Berezovaya Luka settlement of the Bronze Age Elunin culture (Altai, Russian Federation). Using them as defleshers was confirmed by experiments carried out by the authors of the research (Grushin, Valkov 2014, 71, fig. 2: 6). Similar traces can be observed on the Neolithic and Bronze Age tools used for defleshing presented in Fiodorowna-Korobkowa's book about traseology (Fiodorowna-Korobkowa 1999). 


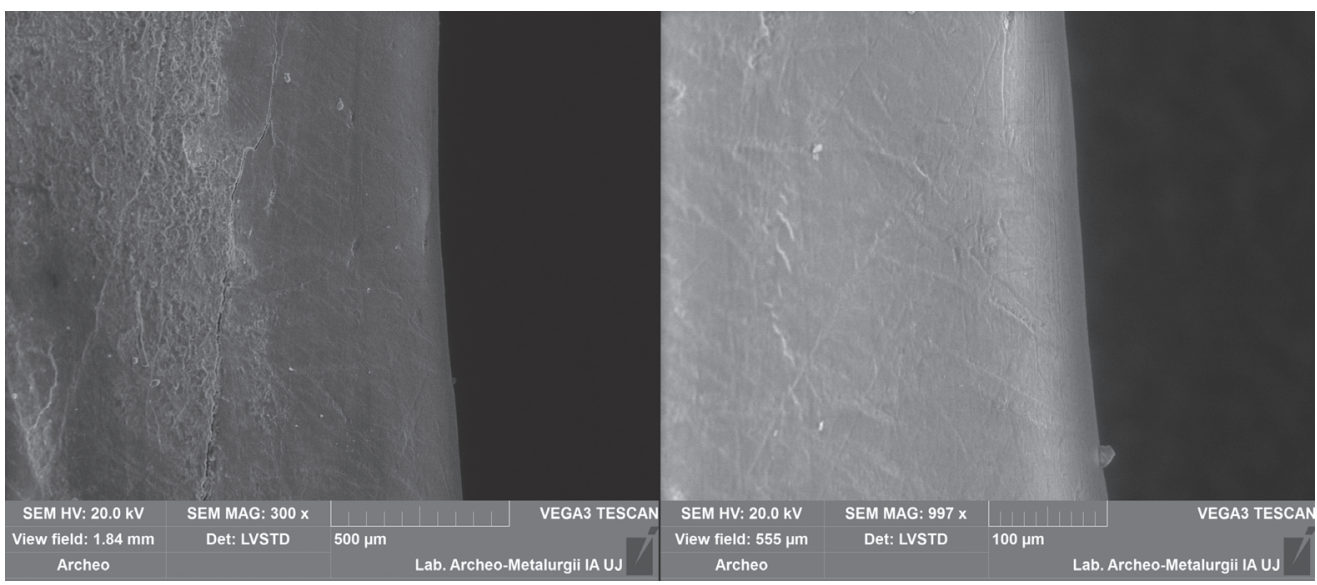

Fig. 6. Micro-traces visible on the Scanning Electron Microscope photographs made by MA Mateusz Biborski in the Archaeometallurgical Laboratory of the Jagiellonian University Institute of Archaeology

\section{Chaîne opératoire}

The assemblage of bone scrapers from Rzemienowice and Michałowice, the considerable amount of manufacturing waste, and the microscopic observation allow us to reconstruct the chaîne opératoire, all the actions conducted for manufacturing the tool. This also allows for investigating the patterns of raw material acquisition, understanding the way it was used, and its use-wear traces (David 2007). It is highly possible that tools were manufactured in butchering places or in their near vicinity. The first step was the dismembering of the mandible from the skull, by chopping the bone on the line between the corpus and the ramus. Waste in the form of chopped-off rami concentrate in the areas where bone scrapers were found. At other parts of the sites, rami of mandibles were also found. In these cases cutting marks (which are clearly butchering marks) were much more common than chopping marks.

During the initial phase, the diastema of the mandible had to be removed as well. These parts of mandibles were found throughout the site without any considerable concentrations. Such waste can be connected with both marrow extraction and manufacturing of bone scrapers (or other bone tools). In order to prepare a suitable plaque for a bone scraper, the part of the mandible in the teeth part must be chopped off, which allows splitting the mandible into two plaques. After removal of the teeth, and slight processing of the semi-product, two holes of the same diameter were drilled with a the knife on the longer edge. The lack of intensive use-wear traces and characteristic traces of hafting (Fig. 5: 2) in this part of the tool confirm that holes were used to attach the handle. Perhaps the handles were wooden, and so could not preserve in such soil conditions.

The working edge was sharpened and formed into a notched shape. With the increasing wearing out of the tool, the notches gradually disappeared, which in some tools resulted in a wavy shape of the working edge (Fig. 7). Notched edges can be observed on many other hide-working tools made of scapulae (Northe 2001). Particularly similar in this respect are tools from the site of Miciurin-Odaia (Noua-Sabatinovka culture, Moldova), which is dated to the Bronze Age (Morgenstern 2011, 165, 170).

The working edge was probably repeatedly re-sharpened with its wear. Experiments show that re-sharpening the bone scraper is important for hide-working (Sidera 1993; Christidou, 


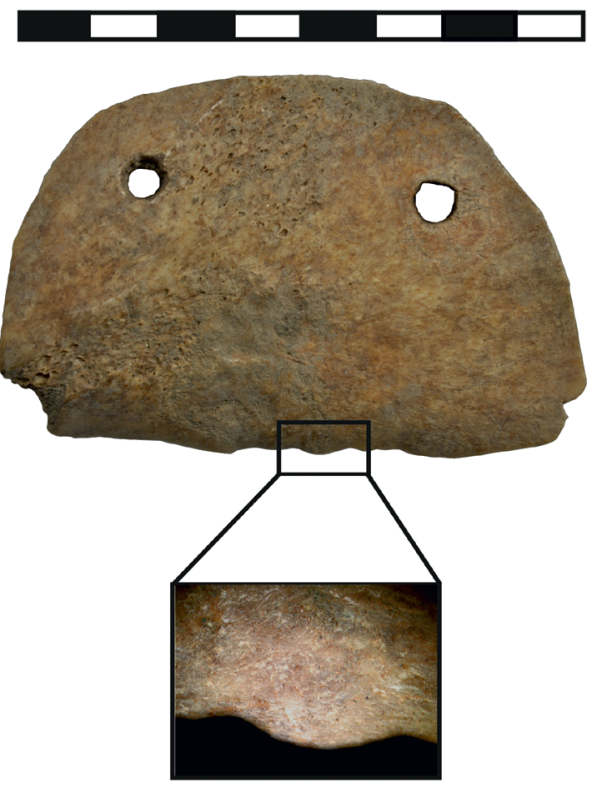

Fig. 7. Traces of wear on a scraper from Rzemienowice
Legrand-Pineau 2003, 386, 389). This process must lead to a reduction of the tool's size.

The fact that scrapers were found at the place of their manufacturing may mean that they were also used at the same place. Thus, one can assume that butchering, defleshing and manufacturing of bone scrapers from mandibles (or other bones) were all carried out at the same place. Manufacturing of such tools does not require a specialized craftsman. The variety of shapes of bone scrapers might stem from the fact that they were manufactured spontaneously, for example by a person who was tanning and dressing leather.

Mandible bones were the most common raw material for manufacturing the bone scrapers described in this paper. However, other bones (like scapula or rib) could be successfully used for the production of tools of the same function. Apparently what was important for craftsmen was producing a thin plaque in the least labour-intensive way.

\section{Bone scrapers from the Neolithic and the Bronze Age}

Similar tools made from scapulae are known from the Corded Ware culture cemetery in Mierzanowice (Uzarowiczowa 1970, 201) and the Early Bronze Age site in Jędrychowice (Bąk $1985,70)$. Their function has not been clearly determined as yet. Based on observation of the smooth, notched working edge, A. Uzarowiczowa assumed they might have been used for stringing threads or fibres (Uzarowiczowa 1970, 224). However, it cannot be excluded that both the Neolithic and the Early Bronze Age examples were used for hide working.

A comprehensive analysis of bone scrapers made from scapulae was presented by Andreas Northe (2001). His research focused on scrapers with a notched edge, found in central Germany, dated back to the period from the Neolithic to the Early Iron Age. Over many years several hypotheses concerning the function of these tools were proposed (Northe 2001 - with further literature). Feustel $(1980,10)$ and Northe $(2001,180)$ distinguished two types of these tools types A and B. Characteristic features of type A are the lack of holes and the lack of a notched edge. Interestingly, apart from tools made from scapulae, identical but bigger examples made from mandibles are also known. Type B is characterized by the presence of holes. Variant B1 has one hole and variant B2 from two to three holes on the edge corresponding to a handle. Variant B1 is dated to the Neolithic and B2 to the Early Iron Age (Northe 2001). Pointing out that the interpretation of the function of these tools is ambiguous, Northe seems inclined to accept the hypothesis positing they were used for hide working. It cannot be excluded that bone scrapers dated back to the Roman Period are a kind of adaptation of scrapers of the B2 type known from the Early Iron Age. 


\section{Chronology}

The bone scrapers described in this text allow for their analysis in terms of the chronology of their occurrence. It should be noted that most of them were found on settlements and only two in burials, which may be the result of burial practices (including cremation) influencing the state of preservation of the bone. Finds discovered in the burial context often allow for a more precise chronological analysis. However, the scrapers described in this text discovered within settlements also allow for certain conclusions in this respect. This stems from the contexts in which they were discovered. Many of them were found in settlement features having a determined, relatively narrow chronology, or in the other cases, in settlements used only in a single chronological phase.

The first of the two specimens known from burials was found in grave 21 in the Przeworsk culture burial ground in Nadkole. The burial also contained a melon-shaped glass bead and a bone comb of Thomas type A.I., allowing for the grave chronology to be narrowed down to the Early Roman Period (Andrzejowski 1998, 21). The second bone scraper discovered in the burial context comes from the burial ground in Masłomęcz (Gr. No. 13), a site dated to the Younger and Late Roman Period and the early phase of the Migration Period (Kokowski 1955, 224, fig. 45).

It should be emphasized here that analogous tools referred to as transverse knives, made of iron, are quite often found in burials of the Przeworsk culture ${ }^{15}$ (Czarnecka 2018, 292). Known iron examples are invariably connected with female burials. The link between bone scrapers and iron tools found in graves was already noticed in the publication concerning the site in Zadowice (Siciński 2011, 59). Most frequently those tools were discovered in graves dated to the Late pre-Roman Period and, above all, to the Early Roman Period.

The finds from Przeworsk culture settlements are similarly dated. The finds from Michałowice and Zagórzyce described in this text do not have the context of well-dated features, but in these two cases the chronology of these tools is confined by the chronology of the entire site, which spans the Late Pre-Roman Period and the Early Roman Period. Due to a rich collection of pottery characteristic of the Early Roman Period, the scraper found in Rzemienowice in feature no. 5 should also be associated with this chronological phase. The fragmentarily preserved second tool from Rzemienowice was discovered in a feature (no. 1) dated by wheel-made pottery to the Late Roman Period. However, there were also finds from older chronological horizons found in this pit in a secondary context, therefore one cannot exclude the possibility that the described fragment might be connected with earlier phases of the settlement occupation. ${ }^{16}$

Among the analogous finds discovered on settlements, the earliest one, dated to the Late Pre-Roman Period, is the scraper from Różyce Stara Wieś site 8 (building 1) (Skowron 2006, 80-81, pl. LXIII: 4). At the same time this is probably the only example to be dated so early. The vast majority of the other finds should be associated with the Early Roman Period. The scrapers found in features dated to the mentioned chronological horizon come from

\footnotetext{
${ }^{15}$ There are known cases of secondary use of such knives, for the making of casket locks (Czarnecka 2018, 292).

${ }^{16}$ This hypothesis is supported by finds from other chronological phases within the Iron Age (i.e. the La Tène Period), and a fragment of the stone axe which is probably connected with the Early Bronze Age. Obviously one cannot be certain in this matter.
} 
Kraków-Nowa Huta (Mogiła), Oględówek, Zadowice, Piwonice and Nieszawa Kolonia. ${ }^{17}$ The chronology of finds from Krusza-Zamkowa site 3 is uncertain. Only a broad dating to the Roman Period is possible in the case of finds from Jakuszowice, discovered within the accumulation layer (layer I). The majority of the finds from this layer are associated with the Younger and Late Roman Periods (Rodzińska-Nowak 2006, 13). ${ }^{18}$

\section{Summary}

As a result of the study it is possible to conclude that bone scrapers were widely used by Przeworsk culture craftsmen. Such a conclusion is supported by the quantity of those finds from recently excavated sites - which have been excavated on a small scale. This fact also brings up the question of the state of research and publication of various bone tools, which are rarely included in in-depth analyses of archaeological finds from Late Pre-Roman Period and Roman Period sites.

The subject has a further research capacity, as there are numerous iron equivalents of the described bone scrapers known from the graves of the Przeworsk culture. As the objective of the study was to determine the function of bone scrapers, the analysis of iron examples found in burials exceeds the scope of this article. The ethnographic studies ${ }^{19}$ of similar tools demonstrate their multi-functional character, but micro-trace analysis on the specimens presented here suggests they were used for hide working. Nevertheless, there is a need for further traseological analysis of more numerous groups of finds to support the remarks presented here. It should be noted that bone scrapers are characteristic of the Early Roman Period, as is indicated by the analysis of burial and settlement finds. ${ }^{20}$ Due to the nature of the context of some of the tools found on settlements (feature 1 in Rzemienowice, Jakuszowice, Krusza Zamkowa) it is uncertain whether the described bone scrapers were also used in the Younger Roman Period, and the results presented in this text may be influenced to a certain degree by the current state of research. At the turn of the Early and Younger Roman Periods, significant changes in many branches of the economy are evident, which were influenced by cultural trends originating from the south, including from the Roman Empire. Perhaps as a result of unknown changes in the production process of leather goods the described bone scrapers ceased to be used in later phases of the Roman Period. At least, there is no sufficient evidence available today that would support such a claim.

\footnotetext{
${ }^{17}$ In the case of feature $72 \mathrm{~A}$ ceramic material has not been published. Its dating to the Early Roman Period is suggested based on the published pottery fragments from feature 72B (Stasiak-Cyran 2016, 31, pl. LXX:5, 6), which according to the authors of the study was functionally connected with feature 72A. ${ }^{18}$ It is important to remark that within accumulation/cultural layers, there are often present artefacts of earlier chronology which originate from features of earlier date disturbed or damaged during later settlement phases. Such a possibility cannot be ruled out in the case of the Jakuszowice site.

${ }^{19}$ Similar hide-working tools are known from distant cultures, geographical regions and periods of time and are made from different material including stone, bone and metal. Pueblo Indians used notched bone tools for leather softening and removing animal hair (Mason 1889, 583). Bone scrapers with a notched edge (but made from Cervidae metapodials) are known from ethnographic research on North American Indians (Feustel 1980, 17; Morgenstern 2011, 170). The Inuit people used reindeer scapula for defleshing and leather softening (McGhee 1972, 94).

${ }^{20}$ The only example of a bone scraper which can be dated back to the Younger Roman Period is the find from Masłomęcz.
} 


\section{Płaskie skrobacze wykonane z kości z okresu przedrzymskiego i rzymskiego}

\section{na ziemiach polskich}

Przeprowadzone badania pozwalają wnioskować, że płaskie kościane skrobacze były powszechnie użytkowane w gospodarce ludności kultury przeworskiej. Wniosek ten jest poparty znacznym przyrostem liczby tego typu zabytków, pochodzących w dużej mierze z ostatnio prowadzonych wykopalisk, które prowadzone są na małą skalę. Fakt ten zwraca również uwagę na kwestię stanu badań i publikacji rozmaitych narzędzi kościanych, które rzadko stanowią przedmiot głębokiej analizy w przypadku badań archeologicznych nad okresem przedrzymkim i okresem wpływów rzymskich.

Zagadnienie niewątpliwie wymaga dalszych badań, zwłaszcza zważywszy na fakt istnienia żelaznych odpowiedników opisanych tu kościanych skrobaczy, znajdowanych w grobach kultury przeworskiej. Jako że celem tego opracowania jest podjęcie próby zidentyfikowania funkcji kościanych skrobaczy, żelazne egzemplarze znane z wyposażenia grobowego wykraczają poza ramy przyjętych tu założeń badawczych. Badania etnograficzne pokazują, że podobne przedmioty często były wielofunkcyjne, aczkolwiek analiza traseologiczna przebadanych przedmiotów zdaje się potwierdzać hipotezę o używaniu ich w pracach garbarniczych (przede wszystkim ściągania mizdry). Niemniej jednak, istnieje potrzeba podjęcia dalszych analiz traseologicznych na większej liczbie narzędzi w celu potwierdzenia przedstawionych tez. Należy zauważyć, że kościane skrobacze są znajdowane w obiektach datowanych na wczesny okres wpływów rzymskich, na co wskazują wyniki analiz znalezisk z grobów i osad. Wziąwszy pod uwagę kontekst niektórych skrobaczy znalezionych na osadach (obiekt $1 \mathrm{w}$ Rzemienowicach, Jakuszowice, Krusza Zamkowa), nie można stwierdzić jednoznacznie czy opisywane narzędzia występowały także w młodszym okresie rzymskim. Zaawansowanie obecnego stanu badań może w pewnym stopniu wpływać na wnioski przedstawione w tej pracy. Na przełomie wczesnego i młodszego okresu wpływów rzymskich, widoczne są istotne zmiany w wielu gałęziach gospodarki, na co wpływ miały impulsy kulturowe pochodzące z południa, w tym - z Cesarstwa Rzymskiego. Być może w wyniku nieznanych przemian w procesie produkcji wyrobów skórzanych, kościane skrobacze nie były używane w późniejszych fazach okresu wpływów rzymskich, lub obecnie nie ma wystarczających dowodów na poparcie takiego stwierdzenia.

\section{References}

Andrzejowski J., 1998 Nadkole 2. A Cemetery of the Przeworsk Culture in Eastern Poland, Monumenta Archaeologica Barbarica, 5, Kraków.

Bąk U., 1985 Knochenerzeugnisse aus der frühbronzezeitlichen Siedlung Jędrychowice, Woiw. Opole, (in:) M. Gedl. (ed.), Frühbronzezeitliche befestigte Siedlungen in Mitteleuropa, Materialien der internationalen Arbeitstagung vom 20. bis zum 22. September 1983 in Kraków, Archaeologia Interregionalis, 6, Warszawa, pp. 69-85.

Binford L. R., 1981 Bones: Ancient Men and Modern Myths, New York - London.

Bulas J., Kasiński M., Juźwińska G., 2019 House or workshop? A case study of two pit-houses at the Iron Age settlement site of Michałowice, Kazimierza Wielka county (Poland), (in:) D. C. Cowley, M. Fernández-Götz, T. Romankiewicz, H. Wendling (eds.), Rural Settlement - relating buildings, landscape, and people in the European Iron Age, Leiden, pp. 153-156. 
Christidou R., Legrand-Pineau A., 2005 Hide working and bone tools: experimentation design and applications, (in:) H. Luik, A. M. Choyke, C. E. Batey, L. Lõugas (eds.), From Hooves to Horns, from Mollusc to Mammoth: Manufacture and Use of Bone Artefacts fro Prehistoric Times to the Present, Muinasaja Teadus, 15, Tallinn, pp. 385-396.

Cofta-Broniewska A., 1979 Grupa kruszańska kultury przeworskiej. Ze studiów nad rozwojem regionalizmu spoleczeństw Kujaw, Poznań.

Czarnecka K., 2018 Zapobiegliwy kowal - recycling w kuźni. Ciekawe znalezisko okuć skrzynki z cmentarzyska kultury przeworskiej w Garwolinie, (in:) B. Niezabitowska-Wiśniewska, P. Łuczkiewicz, S. Sadowski, M. Stasiak-Cyran, M. Erdrich (eds.), Studia Barbarica. Profesorowi Andrzejowi Kokowskiemu w 65. rocznicę urodzin, t. I, Lublin, pp. 289-295.

David E., 2007 Technology on bone and antler industries: A relevant methodology for characterizing early post-glacial societies ( $9^{\text {th }}-8^{\text {th }}$ millenium BC), (in:) Ch. Gates St.-Pierre, R. Walker (eds.), Bones as Tools. Current Methods and Interpretations in Worked Bone Studies, BAR International Series, 1622, Oxford, pp. 35-50.

Dąbrowski K., Dąbrowska I., 1968 Osada lateńsko-rzymska we wsi Piwonice, pow. Kalisz, Materiały Starożytne, 11, pp. 423-505.

Diakowski M., 2014 Metoda traseologiczna i eksperymentalna w określaniu technologii i funkcji przedmiotów kościanych ze stanowiska nr 1 w Lizawicach, pow. oławski, Śląskie Sprawozdania Archeologiczne, 56, pp. 117-140.

Drzewicz A., 2004 Wyroby z kości i poroża z osiedla obronnego ludności kultury tużyckiej w Biskupinie, Warszawa.

Feustel R., 1980 Neolithische Gerberwerkzeuge aus Knochen, Alt-Thüringen, 17, pp. 7-18.

Gryaznov M. P., 1956 Istoriya drevnih plemen verhney Obi po raskopkam bliz s. Bolshaya Rechka, Materialy i Issledovaniya po Arheologii SSSR, 48, Moskwa - Leningrad.

Grushin S.P., Valkov I.A., 2014 Peculiarities of Manufacturing and Using Bone Tools for Tanning Purposes by Eluninsky Culture Population, Izvestija Altajskogo gosudarstvennogo universiteta, 84 (2014/4:2), pp. 68-73.

Hachulska-Ledwos R., 1996 Materiały z okresu lateńskiego i wptywów rzymskich ze stanowiska I w Krakowie-Nowej Hucie (Mogiła, rejon szpital-centrum) z 1954, część II, Materiały Archeologiczne Nowej Huty, 19, pp. 13-99.

Kokowski A., 1995 Grupa masłomęcka. Z badań nad przemianami kultury Gotów w młodszym okresie rzymskim, Lublin.

1999 Archeologia Gotów. Goci w Kotlinie Hrubieszowskiej, Lublin.

Lehmann E., 1931 Gezähnte Knochenwerkzeuge aus Mitteldeutschland, Jahresschrift für die Vorgeschichte der sächsisch-thüringischen Länder, 19, pp. 37-43. 
Luik H., Lang V., 2010 Scapular artefacts with serrated edges from fortified settlements of the late bronze age in Estonia, Archaeologia Baltica, 13, pp. 162-174.

Lukasiewicz K., Rajewski Z., 1938 Przedmioty rogowe i kościane z grodu kultury ,,tużyckiej” w Biskupinie, (in:) J. Kostrzewski (ed.), Gród prasłowiański w Biskupinie w powiecie żnińskim. Sprawozdanie z badań w latach 1936 i 1937 z uwzględnieniem lat 1934-1935, Poznań, pp. 41-54.

Malinowski T., 1961 Badania archeologiczne grodziska kultury tużyckiej w Smuszewie, pow. Wagrowiec, Sprawozdania Archeologiczne, 13, pp. 65-78.

Mărgărit M., 2017 Spatulas and abraded astragalus: Two types of tools used to process ceramics? Examples from the Romanian prehistory, Quaternary International, 438, pp. 201-211.

Mason O. T., 1891 Aboriginal skin dressing, Report of the United States National Museum for the year ending June 30, 1889, Washington, pp. 553-589.

McGeeh R., 1972 Copper Eskimo Prehistory, National Museums of Canada, Publications in Archaeology, 2, Ottawa.

Morgenstern P., 2011 Typical hide working tools from the late Bronze Age of Moldova, (in:) J. Baron, B. Kufel-Diakowska (eds.), Written in Bones. Studies on technological and social contexts of past faunal skeletal remains, Wrocław, pp. 165-172.

Niemiec D., 1999 Osady kultury przeworskiej w Oględówku stan. 1 i Samostrzatowie stan. 1, pow. Pińczów, woj. świętokrzyskie, Kraków, M. A. Thesis, Archive of the Institute of Archaeology of Jagiellonian University (typescript).

Northe A., 2001 Notched implements made of scapulae - still a problem, (in:) A. M. Choyke, L. Bartosiewicz (eds.), Crafting Bone: Skeletal Technologies through Time and Space. Proceedings of the $2^{\text {nd }}$ meeting of the (ICAZ) Worked Bone Research Group Budapest 31 August -5 September 1999, BAR International Series, 937, pp. 179-184.

Outram A. K., 2005 Distinguishing bone fat exploitation from other taphonomic processes: what caused the high level of bone fragmentation at the Middle Neolithic site of Ajvide, Gotland?, (in:) J. Mulville, A. K. Outram (eds.), The Zooarchaeology of Fats, Oils, Milk and Dairying, Oxford, pp. 32-43.

Rajewski Z., 1950 Przedmioty z rogu i kości i obróbka obu surowców w grodach łużyckich z wczesnego okresu żelaznego, (in:) J. Kostrzewski (ed.), III Sprawozdanie z prac wykopaliskowych w grodzie kultury łużyckiej w Biskupinie w powiecie żnińskim za lata 1938-1939 i 1946-1948, Poznań, pp. $171-182$.

Rašková Zelinková M., 2010 Reconstructing the "Chaîne Opératoire” of Skin Processing in Pavlovian Bone Artifacts from Dolni Věstonice I, Czech Republic, (in:) A. Legrand-Pineau, I. Sidéra, N. Buc, E. David, V. Scheinsohn (eds.), Ancient and Modern Bone Artefacts from America to Russia. Cultural, technological and functional signature, BAR International Series, 2136, Oxford, pp. 191-200. 
Rodzińska-Nowak J., 2006 Jakuszowice, stanowisko 2. Ceramika z osady kultury przeworskiej z młodszego i późnego okresu wplywów rzymskich i wczesnej fazy okresu wędrówek ludów, Zeszyty Naukowe Uniwersytetu Jagiellońskiego, Prace Archeologiczne, 61, Kraków.

Siciński W., 2011 Zadowice nad Prosną. Zespół osadniczy kultury przeworskiej z okresu wplywów rzymskich, Łódź.

Sidéra I., 1993 Les assemblages osseux en basin parisien et rhénan du VIe au IVe millénaire B.C. Histoire, techno-économie et culture, Paris, $\mathrm{PhD}$ Thesis, Archives of the l'Université Paris-1 (typescript).

Skowron J., 2006 Kultura przeworska w dorzeczu środkowej i dolnej Bzury. Monografia osadnictwa, Poznań.

Stasiak-Cyran M. (ed.), 2016 Nieszawa Kolonia, stanowisko 5, powiat Opole Lubelskie. Interdyscyplinarna monografia osady z okresu rzymskiego, Lublin.

Turnau I., 1983 Polskie skórnictwo, Wrocław - Warszawa - Kraków - Gdańsk - Łódź.

Uzarowiczowa A., 1970 Groby kultury ceramiki sznurowej z cmentarzyska wielokulturowego w Mierzanowicach, pow. Opatów, Wiadomości Archeologiczne, 35, pp. 201-205.

Wiederhold J. D., 2004 Toward the standardization of use-wear studies constructing an analogue to prehistoric hide work, M.A. Thesis, Archives of the Texas A\&M University (typescript).

Zeman T., 2001 Germánská kostěná a parohová industrie doby ř́mské ve středoevropském barbariku, Sborník prací Filozofické fakulty brněnské univerzity, řada M, 6 (2001), pp. 107-147.

Zielińska M., 2004 Bursztyniarstwo, obróbka kości i poroża oraz tkactwo w młodszym okresie przedrzymskim i okresie wpływów rzymskich na stan. 2 w Jakuszowicach, gm. Kazimierza Wielka, woj. świętokrzyskie, Kraków, M.A. Thesis, Archives of the Institute of Archaelogy of Jagiellonian University (typescript).

Zhilin M. G., 2014 Preemstvennost' i transformatsii v razvitii kostianoi industrii butovskoi kul 'tury, Moskva. 
ISSN 0137-3285 